\title{
The Diagnostic and Prognostic Importance of Neurological Findings on SARS-CoV-2 Infection
}

\author{
SARS-CoV-2 Enfeksiyonunda Nörolojik Bulguların Tanısal ve Prognostik Önemi
}

\author{
Dilcan KOTAN ${ }^{1}$ \\ (D) 0000-0002-8624-6321 \\ Taşkın DUMAN ${ }^{2}$ \\ (D) 0000-0002-6552-4193
}

${ }^{1}$ Sakarya University Faculty of Medicine Department of Neurology, Sakarya, Turkey

${ }^{2}$ Mustafa Kemal University Faculty of Medicine Department of Neurology, Hatay, Turkey

\section{Corresponding Author Sorumlu Yazar \\ Dilcan KOTAN \\ dilcankotan@yahoo.com}

Received / Geliş Tarihi : 23.08.2020 Accepted / Kabul Tarihi : 04.10.2020 Available Online /

Çevrimiçi Yayın Tarihi : 25.11.2020

\begin{abstract}
The coronavirus invades the nervous system with the spread we call neuroinvasion, and "cytokine storm" becomes an important factor affecting the course of the disease. Serious damage occurs in the brain and other organs as a result of cytokine storm. Evidence is accumulating that the coronavirus, which infects millions of people all over the world, affects both the central and peripheral nervous system and muscles as well as the respiratory tract. Increasing evidence has revealed neurological involvement in 36-54\% of the patients, which corresponds to almost one in every 2 or 3 patients. In severe acute respiratory syndrome coronavirus 2 (SARS-CoV-2) patients, we frequently encounter neurological symptoms such as smell and taste disturbances, fatigue and muscle pain, headache, nausea, vomiting, impaired consciousness, numbness in hands and feet. To a lesser extent, we encounter neurological handicaps such as dizziness, inflammation of the meninges, loss of myelin in nerve tissue, muscle inflammation, and severe rhabdomyolysis. Some of the nervous system diseases accompanying SARS-CoV-2 disease recover with complete or partial sequelae. Observation of permanent dysfunction in patients with neurological findings draws attention to the importance of a detailed neurological evaluation in the examination of these cases.

Keywords: SARS-CoV-2; neurological involvement; dysfunction.
\end{abstract}

ÖZ

Koronavirüsü, nöroinvazyon adını verdiğimiz yayılımla sinir sistemini tutmakta, 'sitokin fırtınası' hastalığın gidişatını etkileyen önemli bir faktör olmaktadır. Sitokin firtınası sonucunda beyin ve diğer organlarda ciddi hasarlar ortaya çıkmaktadır. Tüm dünyada milyonlarca kişiyi enfekte eden koronavirüsün solunum yollarının yanı sıra hem merkezi hem de periferik sinirleri ve kas sistemini etkilediğini gösteren kanıtlar gün geçtikçe birikmektedir. Artan kanıtlar, hastaların \%36-54'ünde yani neredeyse her 2 veya 3 hastanın birinde nörolojik tutulumu ortaya koymuştur. Şiddetli akut solunum yolu sendromu koronavirüsü 2 (severe acute respiratory syndrome coronavirus 2 , SARS-CoV-2) hastalarında koku ve tat bozuklukları, yorgunluk ve kas ağrısı, baş ağrısı, bulantı, kusma, bilinç bozukluğu, el ve ayaklarda uyuşma gibi nörolojik belirtilerle sıç̧a karşılaşıyoruz. Daha az olarak ise baş dönmesi, beyin zarı iltihapları, sinir dokusunda miyelin kaybı, kas iltihabı, ağır kas yıkımı gibi nörolojik handikaplara rastlıyoruz. SARS-CoV-2 hastalığına eşlik eden sinir sistemi hastalıklarının bir kısmı tam ya da kısmi sekel ile iyileşmektedir. Nörolojik bulgu gösteren hastalarda kalıcı fonksiyon kaybının gözlenmesi, bu olguların değerlendirilmesinde ayrıntılı nörolojik değerlendirmenin önemine dikkati çekmektedir.

Anahtar kelimeler: SARS-CoV-2; nörolojik tutulum; fonksiyon kaybı. 


\section{INTRODUCTION}

It has been understood with our increasing knowledge and experience that severe acute respiratory syndrome coronavirus 2 (SARS-CoV-2) infection is not limited only to the respiratory tract and that it could also damage the nervous system causing neurological diseases and these damages may sometimes be permanent. Having information on neurological findings of SARS-CoV-2 disease has a guiding importance in terms of early diagnosis and treatment of neurological diseases and public health. In light of scientific research, it could be stated that neurological findings are observed more on coronavirus cases. SARS-CoV-2 could enter the nervous system through retrograde neuronal or hematogenous pathway. As the severity and course of the disease increase, the frequency of encountering nervous systemrelated findings has increased. Evaluating findings related to the nervous system in SARS-CoV-2 cases and the early detection and treatment of involvement are of utmost importance in terms of containing the constraint and death caused by the disease (1-3).

\section{CYTOKINE STORM}

The coronavirus attaches itself to the nervous system with a dissemination that we call neuroinvasion while "cytokine storm' is an important factor affecting the course of the disease. As a result of the cytokine storm, serious damage could be observed in brain and other organs (4). In action mechanisms in the nervous system, direct invasion, hematogenous and neuronal dissemination, hypoxic and immune damage have been found responsible (2).

While coronavirus disease 2019 (COVID-19) moves to a severe stage in some of the infected individuals, most people recover within an average of 14 days. Although we cannot fully explain what determines this clinical course with our current knowledge, there is some evidence indicating a relationship between disease severity and proinflammatory cytokine levels. Recovery from COVID19 is only possible with the generation of an effective immune response. In fact, it has even been suggested that the main cause of the existing tissue damage may be related to immune dysregulation and increased release of proinflammatory cytokines during the formation of protective antibodies against the disease $(4,5)$. This theory also explains the radiological finding of increased lung involvement in the recovery phase $(6,7)$.

The limitation of virus spread in COVID-19 is possible through the production of proinflammatory cytokines and the immune response that enables the activation of $\mathrm{T}$ cells. When tissue damage caused by the virus affecting the endothelium results in over-activation of macrophages and granulocytes, and induces excessive production of proinflammatory cytokines, a clinical picture resulting in severe tissue damage termed "Cytokine Storm" occurs (8-10).

In COVID-19, various cytokines and chemokines play a role in the course of the disease. IL-2, IL-6, IL-8, IL-10 and TNF- $\alpha$ plasma levels are significantly higher in cases with poor clinical prognosis compared to patients with good clinical prognosis (11). A close relationship has been found between IL-6 level, which has significant proinflammatory characteristics, and lymphocyte subgroups in peripheral blood. In laboratory tests, lymphocyte levels are normal or decreased in many patients. With both $\mathrm{T}$ and $\mathrm{B}$ cell immunity playing a role in immunity formation against COVID-19, it is thought that this disease intersects with some autoimmune neurological diseases such as multiple sclerosis (MS) in some common pathophysiological mechanisms.

\section{Corticosteroid Administration in Autoimmune Neurological Diseases}

Corticosteroids are frequently used orally or intravenously (IV) in neurology practice. Corticosteroids are commonly used in acute phase and maintenance treatment in patients with MS, myasthenia graves, chronic inflammatory neuropathy and myopathy. There is no consensus yet on steroid applications during the pandemic. Determining whether the person is in the asymptomatic period for COVID-19 and, if so, reaching a diagnosis to reduce the risk of the adverse reactions of high-dose corticosteroids do not seem easy with the current capabilities. For example, although there is variability between centers in patients with MS, there are also emerging trends such as waiting for mild attacks to pass without treatment or recommending short-term intravenous methylprednisolone (IVMP) without resorting to neuroimaging.

During the COVID-19 pandemic, both patients and physicians feel anxiety regarding the increased risk of contamination during admission to the hospital, commuting by public transport, frequent use of public bathrooms, closure of day treatment centers, and contamination due to the environment during intravenous treatment. Although it is theoretically possible that corticosteroid treatments may increase the spread of viral infection in the early period in case of COVID-19 transmission, limited case reports so far report no such issue $(12,13)$. If the physician decides to use corticosteroids according to the severity of the disease, use of nonsteroidal drugs in the last three weeks should be questioned. If fever and pulse are required, cardiac beat monitoring, complete blood count (CBC), liver function tests (LFT), creatine kinase $(\mathrm{CK}), \mathrm{C}$-reactive protein (CRP), ferritin, D-Dimer, lactate dehydrogenase (LDH), and fibrinogen values should be checked $(14,15)$. During this process, IV treatments may be planned for shorter periods, preferably for an average of 5-7 days (12).

\section{Which Neurological Diseases and Findings did the COVID-19 Pandemic Affect?}

Evidence demonstrating that the SARS-CoV-2 virus, infecting millions of people all over the world and affecting both central and peripheral nervous system and muscles in addition to the respiratory tract has been on the increase. We could categorize neurological findings that we see on SARS-CoV-2 infection as findings related to central and peripheral nervous system and musculoskeletal findings. It is sometimes possible to encounter some of these findings in a single patient at the same time. Increasing evidence has demonstrated neurological involvement in $36 \%$ of patients, which corresponds to almost one-third of all patients. Among common neurological symptoms of SARS-CoV-2 infection are smell and taste disorders, lethargy and myalgia, headache, 
nausea, vomiting, impaired consciousness, and numbness in hand and feet. Less common neurological cases are vertigo, encephalitis, central and peripheral demyelination, myositis, and rhabdomyolysis $(2,3,16)$.

One of the most common symptoms of SARS-CoV-2 infection is sudden loss of smell and taste. In coronavirus patients with loss of smell and taste, one in every four cases is asymptomatic, one in every four cases is at the early stage, and one in every four cases has severe findings. The disease could even progress without any other symptoms but loss of smell and taste. Since early diagnosis is important for this disease, having information on early signs such as loss of smell and/or taste could be greatly beneficial for diagnosis and patient isolation. The sudden loss of smell and taste, observed at the earliest stage of SARS-CoV-2 infection, is caused by the virus entering nose and reaching the olfactory neuron neighboring the cribriform plate. Although the disease is treated, the loss of smell could last for weeks in some cases (17-20).

Headache could sometimes be the alarm symptom in the SARS-CoV-2 disease. Unprecedented severe headaches could be guiding for SARS-CoV-2 diagnosis during the pandemic. We predict that the virus, through the unipolar receptors perceiving smell in the nose or a direct effect on the trigeminal nerve, enters the brain and could cause headache. Our literature information corresponds to 12$19 \%$, which means that almost one in every five patients has headache as the primary sign or an accompanying sign $(21,22)$

Scientific data and patient observations suggesting lethargy, myalgia, and increasing serum CK are increasing. This could be explained by the damage of high cytokines on skeletal muscles. Neurological symptoms accompanying SARS-CoV-2 infection such as myositis, critical illness neuropathy and/or myopathy, rhabdomyolysis, and inflammatory neuropathy such as Guillain-Barre syndrome have been treated with partial or total sequelae while they may cause permanent dysfunction in some cases $(23,24)$.

In order to prevent deaths related to the virus in our country, meticulous and assiduous studies are conducted. We observe that cerebrovascular diseases are a common mortality cause in all age groups, especially more in chronic patients, in the SARS-CoV-2 disease. Complications such as thrombosis and stroke determine the progression of infection and one of the most important indicators is thought to be D-dimer levels. Compared to deaths related to ischemic stroke and stroke, which have been more common in China and Europe, we strongly believe that D-dimer follow-up, mentioned in the guidelines formed by the Ministry of Health in Turkey, as well as the antiaggregant administration have remarkably contributed to the current good state and the low levels of mortality rate in our country $(25,26)$.

\footnotetext{
When Exactly is the COVID-19 Pandemia Normalization Happening?

One of the two most important factors determining normalization in a pandemic is natural immunity, in other words, recovering from the infection, and the other is vaccination. COVID-19 IgG positivity is an indicator that a person is immune to the disease, but it is not yet clear
}

with the available data whether it will be sufficient to return to normal social life. The quality of the antibodies produced after the disease seems to be more important than antibody positivity.

\section{SARS-CoV-2 Immunity and Vaccines}

When COVID-19 vaccines become available, it is thought that the effect will probably be low, especially in those receiving immunosuppressive therapy, and it will be even less effective in individuals with suppressed B cells. If the vaccine becomes available in daily practice, lymphocyte subgroups and immunoglobulins can be checked to give an idea before vaccination in autoimmune neurological diseases.

It is obvious that when the vaccine is developed, vaccination before initiating treatment in individuals with suspected risk of autoimmune disease and determining that vaccine produces sufficient antibody titer will be included in treatment algorithms for people receiving immunosuppressive therapy. For example, inactivated vaccines are considered safe for people with MS. It is generally accepted that vaccines administered during treatment with interferons, glatiramer acetate, dimethylfumarate, teriflunomide and natalizumab maintain their efficacy to a large extent and vaccines administered during treatment with fingolimod maintain their efficacy partially (27-29).

Live vaccines such as measles, polio, smallpox, chickenpox, and BCG should be avoided in patients receiving immunosuppressive therapy and taking corticosteroids for a long time. Tetanus vaccine is recommended during pregnancy and when necessary, even during an attack period. Necessary vaccines are recommended to be completed especially in the period before immunosuppressive treatments are initiated $(28,29)$.

If the COVID-19 vaccine enters daily clinical practice, it seems that when and under what conditions we will vaccinate our patients, and in particular how effective the vaccine is in patients receiving immunosuppressive treatment and whether there is an increase in the frequency of attacks after vaccination will form the outline of our discussions in the near future (30).

\section{CONCLUSION}

It has been understood with our increasing knowledge and experience that SARS-CoV-2 infection is not limited only to the respiratory tract and that it could also damage the nervous system causing neurological diseases and these damages may sometimes be permanent. Having information on neurological findings of SARS-CoV-2 disease has a guiding importance in terms of the early diagnosis and treatment of neurological diseases and public health. Neurological findings and follow-up approaches in this article reflect the current status. We believe that these should be reviewed once ample evidence-based information is accumulated.

Conflict of Interest: None declared by the authors.

Financial Disclosure: None declared by the authors.

Acknowledgements: None declared by the authors. 


\section{REFERENCES}

1. Siniscalchi A, Gallelli L. Could COVID-19 represent a negative prognostic factor in patients with stroke? Infect Control Hosp Epidemiol. 2020;41(9):1115-6.

2. Wu Y, Xu X, Chen Z, Duan J, Hashimoto K, Yang L, et al. Nervous system involvement after infection with COVID-19 and other coronaviruses. Brain Behav Immun. 2020;87:18-22.

3. Mao L, Jin H, Wang M, Hu Y, Chen S, He Q, et al. Neurological manifestations of hospitalized patients with coronavirus disease 2019 in Wuhan, China. JAMA Neurol. 2020;77(6):683-90.

4. Wan S, Yi Q, Fan S, Lv J, Zhang X, Guo L, et al. Characteristics of lymphocyte subsets and cytokines in peripheral blood of 123 hospitalized patients with 2019 novel coronavirus pneumonia (NCP). MedRxiv. 2020. doi: 10.1101/2020.02.10.20021832

5. Yang Y, Shen C, Li J, Yuan J, Yang M, Wang F, et al. Exuberant elevation of IP-10, MCP-3 and IL-1ra during SARS-CoV-2 infection is associated with disease severity and fatal outcome. MedRxiv. 2020. doi: 10.1101/2020.03.02.20029975

6. Zahir JP, Felix AR, Miyara M. A nicotinic hypothesis for COVID-19 with preventive and therapeutic implications. C R Biol. 2020;343(1):33-9.

7. Tufan A, Avanoğlu Güler A, Matucci-Cerinic M. COVID-19, immune system response, hyperinflammation and repurposing antirheumatic drugs. Turk J Med Sci. 2020;50(SI-1):620-32.

8. George MR. Hemophagocytic lymphohistiocytosis: review of etiologies and management. J Blood Med. 2014;5:69-86

9. McGonagle D, Sharif K, O'Regan A, Bridgewood C. The role of cytokines including interleukin- 6 in COVID-19 induced pneumonia and macrophage activation syndrome-like disease. Autoimmun Rev. 2020;19(6):102537.

10. Moore JB, June CH. Cytokine release syndrome in severe COVID-19. Science. 2020;368(6490):473-4.

11. Qin C, Zhou L, Hu Z, Zhang S, Yang S, Tao Y, et al. Dysregulation of immune response in patients with coronavirus 2019 (COVID-19) in Wuhan, China. Clin Infect Dis. 2020;71(15):762-8.

12. Brownlee W, Bourdette D, Broadley S, Killestein J, Ciccarelli O. Treating multiple sclerosis and neuromyelitis optica spectrum disorder during the COVID-19 pandemic. Neurology. 2020;94(22):949-52.

13. msif.org [Internet]. Multiple Sclerosis International Federation. Global COVID-19 advice for people with MS. [Cited: 2020 March 26]. Available from: http://www.msif.org/wpcontent/uploads/2020/03/MSIF-Global-advice-onCOVID-19-for-people-with-MS.docx-1.pdf

14. Mehta P, McAuley DF, Brown M, Sanchez E, Tattersall RS, Manson JJ, et al. COVID-19: consider cytokine storm syndromes and immunosuppression. Lancet. 2020;395(10229):1033-4.

15. Russell CD, Millar JE, Baillie JK. Clinical evidence does not support corticosteroid treatment for 2019nCoV lung injury. Lancet. 2020;395(10223):473-5.

16. Nath A. Neurologic complications of coronavirus infections. Neurology. 2020;94(19):809-10.

17. Lechien JR, Chiesa-Estomba CM, De Siati DR, Horoi
M, Le Bon SD, Rodriguez A, et al. Olfactory and gustatory dysfunctions as a clinical presentation of mild-to-moderate forms of the coronavirus disease (COVID-19): a multicenter European study. Eur Arch Otorhinolaryngol. 2020;277(8):2251-61.

18. Galougahi MK, Ghorbani J, Bakhshayeshkaram M, Naeini AS, Haseli S. Olfactory bulb magnetic resonance imaging in SARS-CoV-2-induced anosmia: the first report. Acad Radiol. 2020;27(6):892-3.

19. Karimi-Galougahi M, Yousefi-Koma A, Bakhshayeshkaram M, Raad N, Haseli S. ${ }^{18}$ FDG PET/CT scan reveals hypoactive orbitofrontal cortex in anosmia of COVID-19. Acad Radiol. 2020;27(7):1042-3.

20. De Maria A, Varese P, Dentone C, Barisione E, Bassetti M. High prevalence of olfactory and taste disorder during SARS-CoV-2 infection in outpatients. J Med Virol. 2020; [Epub ahead of print]. doi: 10.1002/jmv.25995.

21. Bolay H, Gul A, Baykan B. COVID-19 is a real headache. Headache. 2020; [Epub ahead of print]. doi: 10.1111/head.13856.

22. Borges do Nascimento IJ, Cacic N, Abdulazeem HM, von Groote TC, Jayarajah U, Weerasekara I, et al. Novel coronavirus infection (COVID-19) in humans: a scoping review and meta-analysis. J Clin Med. 2020;9(4):941.

23. Guidon AC, Amato AA. COVID-19 and neuromuscular disorders. Neurology. 2020;94(22):959-69.

24. Solé G, Salort-Campana E, Pereon Y, Stojkovic T, Wahbi K, Cintas P, et al. Guidance for the care of neuromuscular patients during the COVID-19 pandemic outbreak from the French Rare Health Care for Neuromuscular Diseases Network. Rev Neurol (Paris). 2020;176(6):507-15.

25. Zhou Y, Li W, Wang D, Mao L, Jin H, Li Y, et al. Clinical time course of COVID-19, its neurological manifestation and some thoughts on its management. Stroke Vasc Neurol. 2020;5(2):177-9.

26. Qureshi AI, Abd-Allah F, Alsenani F, Aytac E, Borhani-Haghighi A, Ciccone A, et al. Management of acute ischemic stroke in patients with COVID-19 infection: report of an international panel. Int J Stroke. 2020;15(5):540-54.

27. who.int [Internet]. World Health Organization. "Immunity passports" in the context of COVID-19, scientific brief. [Cited: 2020 April 24]. Available from: https://apps.who.int/iris/rest/bitstreams/1275788/retrieve

28. aan.com [Internet]. American Academy of Neurology. AAN issues guideline on vaccines and multiple sclerosis [Cited: 2020 March 26]. Available from: https://www.aan.com/PressRoom/Home/PressRelease 12745 .

29. Farez MF, Correale J, Armstrong MJ, Rae-Grant A, Gloss D, Donley D, et al. Practice guideline update summary: vaccine-preventable infections and immunization in multiple sclerosis. Report of the Guideline Development, Dissemination, and Implementation Subcommittee of the American Academy of Neurology. Neurology. 2019;93(13):584-94.

30. Bar-Zeev N, Inglesby T. COVID-19 vaccines: early success and remaining challenges. Lancet. 2020;396(10255):868-9. 